\title{
The Gut Microbiota of the Insect Infraorder Pentatomomorpha (Hemiptera: Heteroptera) for the Light of Ecology and Evolution
}

\author{
Hongwei Shan, Wei Wu, Zongtao Sun, Jianping Chen and Hongjie Li *
}

check for updates

Citation: Shan, H.; Wu, W.; Sun, Z.; Chen, J.; Li, H. The Gut Microbiota of the Insect Infraorder Pentatomomorpha (Hemiptera: Heteroptera) for the Light of Ecology and Evolution. Microorganisms 2021, 9, 464. https:// doi.org/10.3390/microorganisms9020464

Academic Editor: Michael Poulsen

Received: 27 January 2021

Accepted: 19 February 2021

Published: 23 February 2021

Publisher's Note: MDPI stays neutral with regard to jurisdictional claims in published maps and institutional affiliations.

Copyright: (c) 2021 by the authors. Licensee MDPI, Basel, Switzerland. This article is an open access article distributed under the terms and conditions of the Creative Commons Attribution (CC BY) license (https:/ / creativecommons.org/licenses/by/ $4.0 /)$.
State Key Laboratory for Managing Biotic and Chemical Threats to the Quality and Safety of Agro-products, Key Laboratory of Biotechnology in Plant Protection of Ministry of Agriculture and Zhejiang Province, Institute of Plant Virology, Ningbo University, Ningbo 315211, China; shanhongwei@nbu.edu.cn (H.S.); wuwei_19861115@163.com (W.W.); sunzongtao@nbu.edu.cn (Z.S.); jianpingchen@nbu.edu.cn (J.C.)

* Correspondence: lihongjie@nbu.edu.cn; Tel.: +86-574-87603660

\begin{abstract}
The stinkbugs of the infraorder Pentatomomorpha are a group of important plant sapfeeding insects, which host diverse microorganisms. Some are located in their complex morphological midgut compartments, while some within the specialized bacteriomes of insect hosts. This perpetuation of symbioses through host generations is reinforced via the diverse routes of vertical transmission or environmental acquisition of the symbionts. These symbiotic partners, reside either through the extracellular associations in midgut or intracellular associations in specialized cells, not only have contributed nutritional benefits to the insect hosts but also shaped their ecological and evolutionary basis. The stinkbugs and gut microbe symbioses present a valuable model that provides insights into symbiotic interactions between agricultural insects and microorganisms and may become potential agents for insect pest management.
\end{abstract}

Keywords: stinkbugs; symbiotic organ; gut symbionts; insect-microbe interactions

\section{Introduction}

Hemiptera comprises stinkbugs, aphids, whiteflies, psyllids, planthoppers, leafhoppers, and cicadas, etc., are not only the most important agricultural pests, but also the common vectors that spread plant pathogenic virus, bacteria, phytoplasma and fungi, which lead to severe economic impacts in major crop plants worldwide [1-4]. Major hemipteran insects feed on phloem sap or xylem sap that are nutritionally poor or unbalanced diets for the insect hosts live throughout the life cycle, and consequently, symbiotic associations with beneficial microorganisms to provide a supplementary source of nutrients including essential amino acids and/or vitamins [5-7]. As the exquisite evolutionary adaptations, hemipteran insects have evolved specialized cells, tissues, and/or organs to accommodate and maintain symbiotic microorganisms, such as specialized intestines and even cells called bacteriocytes [8,9]. Most Sternorrhyncha and Auchenorrhyncha includes aphids, whiteflies, and leafhoppers, are associated with primary/obligate symbiotic relationship with bacteria that are presented in the bacteriocytes within the insect body [10]. In contrast, many stinkbugs (Hemiptera: Heteroptera) are lack of bacteriocytes, instead their posterior region of midguts are morphologically differentiated into alternative habitats for housing symbiotic microbiota [11,12]. In addition, various facultative symbionts have been found to provide the insect hosts with parasitoids resistance, heat tolerance or insecticide resistance [13-16], which lead hemipteran insects a tremendously ecological success. These insects maintain these specific beneficial partners between generations either via vertically acquire from parents or horizontally acquire from the environment with diverse routes [17]. Herein, we extensively review the literatures on the mutualistic associations between stinkbugs and their microbial symbionts, therefore provide deeper insights into the ecology and evolution of the gut microbiota in these insects. Specifically, we include (i) the evolutionary trajectory for hosting microbial symbionts across hemipteran insects; 
(ii) the diverse strategies of the microbial acquisition; and (iii) its ecological implications and potentials as a studying model for insect-gut microbiota interactions.

\section{Evolutionary Trajectory for Hosting Microbial Symbionts in Hemiptera}

Mutualistic associations between hemipteran insects and microorganisms are quite omnipresent, particularly in the suborders Sternorrhyncha, Auchenorrhyncha and Heteroptera (with infraorders Cimicomorpha and Pentatomomorpha) (Figure 1) [6,18]. Moreover, these insects have evolved different symbiotic tissues for housing the symbionts over evolutionary time.

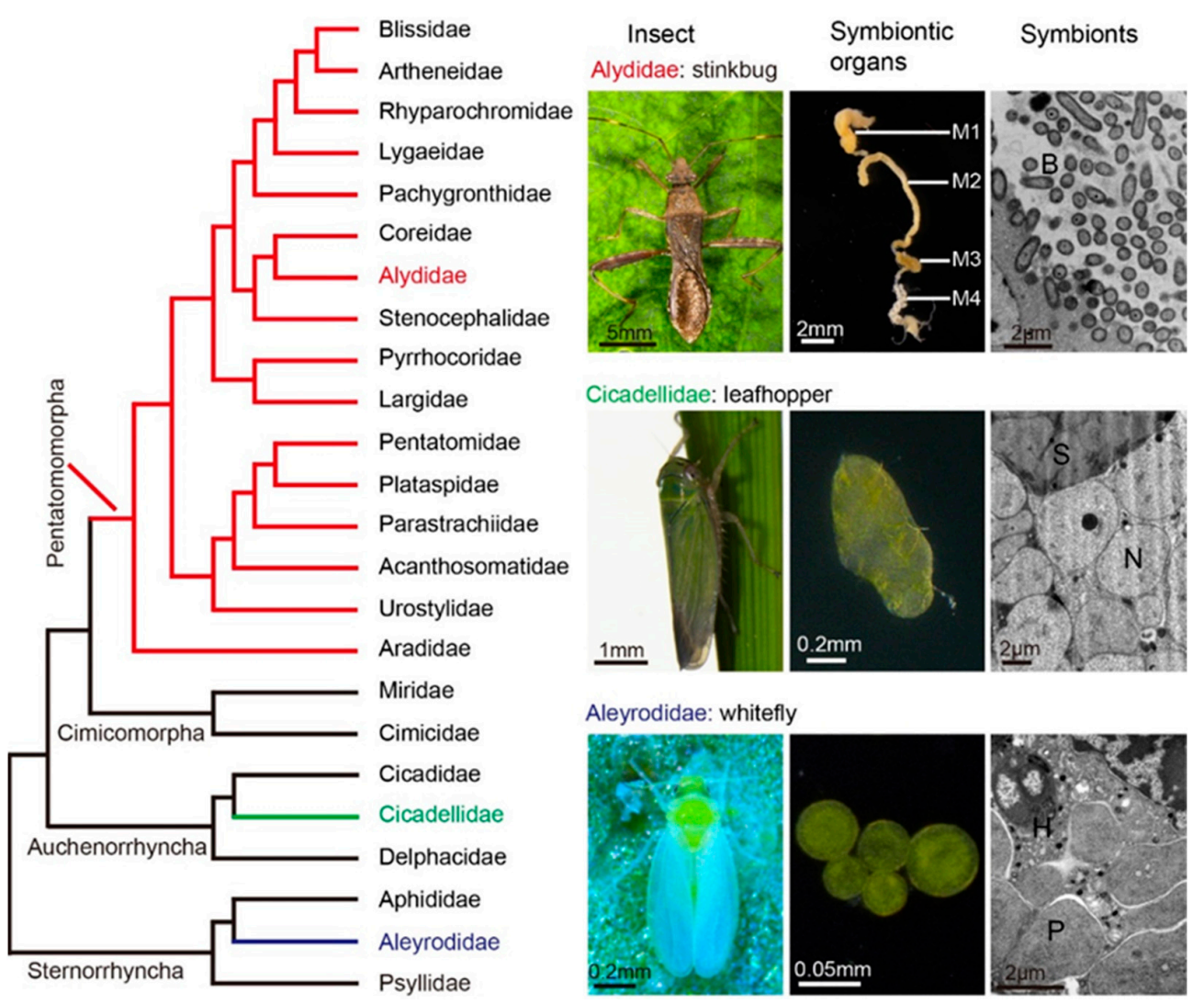

Figure 1. Phylogeny of stinkbugs in Hemiptera. Left panel: A simplified phylogeny of the pentatomomorphan stinkbugs in Hemiptera. The red colored lines indicate the families of stinkbugs. The tree is based on the references $[6,18]$ with slight modification. Right panel: The insect hosts, their symbiotic organs and bacterial symbionts in three representative families of the suborders Heteroptera (the infraorder Pentatomomorpha), Auchenorrhyncha, and Sternorrhyncha. Top images (from left to right): an alydid stinkbug Riptortus pedestris, the four sections of the midgut, and the transmission electron micrographs (TEM) of Burkholderia symbiont in midgut crypts. M1, midgut first section; M2, midgut second section; M3, midgut third section; M4, midgut fourth section with crypts; B: Burkholderia. Middle images: a planthopper Laodelphax striatellus, bacteriome and the micrograph of their dual obligate symbionts Nasuia and Sulcia in bacteriome. N: Nasuia; S: Sulcia. Bottom images: A whitefly Bemisia tabaci, bacteriocytes, and the micrograph of obligate symbiont Portiera and facultative symbiont Hamiltonella in bacteriocyte. P: Portiera; H: Hamiltonella.

\subsection{The intracellular Symbiotic Association of Sternorrhyncha}

Obligate intracellular symbioses are dominant in the Sternorrhyncha (aphids, whiteflies, psyllids, and mealybug, etc.), and the symbionts are mostly restricted in the host specialized cells so-called bacteriocytes (Figure 1 and Table 1) [19-29]. In the well-studied aphids-Buchnera symbiosis, the obligate endosymbionts are embedded in the bacteriocytes located within the body cavities of insect hosts [30]. The symbionts are permanently resid- 
ing in the host bacteriocytes throughout all insect developmental stages, except for the host parthenogenetic reproduction, in which symbionts will leave the bacteriocytes and transmit into the embryo [31]. The intracellular lifestyles drive the genomes of obligate symbionts towards AT-biased nucleotide composition and with significant reduction [32,33]. While the symbiont also retains the genes for the synthesis of all essential amino acids that are almost completely depleted in plant phloem diet of the host [21]. Most aphids contain the obligate Buchnera, but it is absent in some Cerataphidini aphids and replaced by a yeast-like symbiont located in the abdominal hemocoel within the body cavity [34]. In addition, many facultative symbionts are co-inhabited with Buchnera in aphids, such as Hamiltonella defensa, Serratia symbiotica, and Regiella insecticola, are grouped into clusters within secondary bacteriocytes located between the primary bacteriocytes [14]. These facultative symbionts do not appear to perform essential nutritional functions but play important roles in ecological adaptation for host $[14,35,36]$.

The family Aleyrodidae whiteflies, such as Bemisia tabaci and Aleurodicus dugesii, are major agricultural pests causing plant damage and transmitting plant viruses. The whiteflies have dozens of relatively small, roundish and orange bacteriocytes that contain a pleiomorphic obligate bacterium Portiera aleyrodidarum (Figure 1) [37]. They have a unique mode for transmitting bacteriocyte symbionts to progeny, in which the intact bacteriocytes migrate to the ovaries and enter the eggs [38,39]. Moreover, the insects contain several facultative symbionts with scattered distributions. Some symbionts like Hamiltonella defensa, Wolbachia sp., or Arsenophonus sp. share the same symbiotic cell with Portiera and co-located in the cytoplasm of bacteriocyte (Figure 1) [40]. The obligate Portiera provides its host with essential amino acids and carotenoids and while one or several facultative symbionts involve in synthesizing B vitamins and other cofactors [41,42]. Moreover, another facultative symbiont Rickettsia resides in remarkable habitats within whitefly hosts, in which the bacteria occupy most of the insect body cavities that are widespread in the bacteriocytes, midgut, fat body, hemocytes, and hemolymph [43-45]. However, these sap-feeding insects include aphids and whiteflies are found as almost completely absent of gut microbiota $[5,46]$, or as for whiteflies, only associated with some intracellular Rickettsia symbionts that restrictedly inhabit within the midgut epithelial cells [44].

\subsection{The Intracellular Symbiotic Association of Auchenorrhyncha}

Most groups of the Auchenorrhyncha including leafhoppers (the family Cicadellidae), cicadas (the family Cicadidae) and planthoppers (the family Delphacidae) are phloem or xylem feeders, and evolve a pair of symbiotic tissues constitute several specialized cells form a larger structure, often referred as bacteriomes. Unlike the exclusive obligate symbiosis in most Sternorrhyncha, the leafhoppers and cicadas often have dual obligate the symbionts, and usually harbor the obligate symbiont Sulcia muelleri with one other kind of the co-obligate symbiont, e.g., Baumannia cicadellinicola or Nasuia deltocephalinicola in the bacteriomes (Figure 1) [25,47]. In general, the Sulcia has the capacity to synthesize eight of the 10 essential amino acids and another co-obligate symbiont enable to produce the remaining two essential amino acids and other vitamins [25,48]. While symbiont replacements or losses have occurred in some leafhoppers. In the subfamily Ledrinae, Ledra auditura Walker only harbors Sulcia symbiont and the co-obligate symbiont is replaced by yeast-like fungal symbionts within insect fat bodies [49]. Furthermore, some leafhoppers species even lack both obligate symbionts and instead harbor Cardinium symbionts and/or the yeast-like symbiont in their fat bodies to fulfill the nutritional roles for hosts [49,50]. Intriguingly, in the planthoppers (family Delphacidae), those insects are not associated with specifically obligate bacterial symbionts and the obligate association is replaced by the yeast-like symbionts involved in nitrogen recycling of hosts to fulfill the nutritional roles [28]. Meanwhile, a facultative symbiont Wolbachia, a famous reproductive parasite in arthropods, is frequently inhabited in these insects involved in the metabolism of B vitamins to enhance the fecundity of female host insects [51]. 
Table 1. The nutrient related symbionts and their localizations in symbiotic organs of representative the hemipteran insects.

\begin{tabular}{|c|c|c|c|c|c|c|}
\hline \multicolumn{2}{|l|}{ Insects } & \multirow{2}{*}{ Symbionts } & \multirow{2}{*}{ Obligate } & \multirow[b]{2}{*}{ Localization } & \multirow[b]{2}{*}{ Transmission Routes } & \multirow[b]{2}{*}{ References } \\
\hline Suborder/Infraorder/Superfamily & Family & & & & & \\
\hline \multirow[t]{4}{*}{ Sternorrhyncha } & Psyllidae & Carsonella ruddii & + & Bacteriocyte & Ovarial passage & [19] \\
\hline & Aleyrodidae & Portiera aleyrodidarum & + & Bacteriocyte & Ovarial passage & {$[20]$} \\
\hline & Aphididae & Buchnera aphidicola & + & Bacteriocyte & Ovarial passage & {$[21]$} \\
\hline & Pseudococcidae & Tremblaya princeps & + & Bacteriocyte & Ovarial passage & {$[22]$} \\
\hline \multirow[t]{3}{*}{ Cicadomorpha } & Cicadellidae & $\begin{array}{c}\text { Sulcia muelleri and Baumannia } \\
\text { cicadenillicola or Nasuia koganicola }\end{array}$ & + & Bacteriocyte & Ovarial passage & {$[23,24]$} \\
\hline & Cicadidae & S. muelleri and Hodgkinia cicadicola & + & Bacteriocyte & Ovarial passage & [25] \\
\hline & Cercopidae & S. muelleri and Zinderia insecticola & + & Bacteriocyte & Ovarial passage & {$[27]$} \\
\hline \multirow[t]{2}{*}{ Fulgoromorpha } & Delphacidae & Yeast-like symbionts & + & Fat body & Ovarial passage & [28] \\
\hline & Cixiidae & S. muelleri and Vidania fulgoroideae & + & Bacteriocyte & Ovarial passage & [29] \\
\hline \multirow[t]{2}{*}{ Cimicomorpha } & Cimicidae & Wolbachia & + & Bacteriocyte & Ovarial passage & {$[52,53]$} \\
\hline & Miridae & Rickettsia and Wolbachia & - & Bacteriocyte \&Midgut & Ovarial passage & {$[54,55]$} \\
\hline \multicolumn{7}{|l|}{ Pentatomomorpha } \\
\hline \multirow[t]{5}{*}{ Pentatomoidea } & Pentatomidae & Pantoea spp. & + & Midgut (M4) & Egg surface & [56] \\
\hline & Plataspidae & Ishikawaella capsulatus & + & Midgut (M4) & Capsule & [57] \\
\hline & Parastrachiidae & Benitsuchiphilus tojoi & + & Midgut (M4) & Egg surface & {$[58,59]$} \\
\hline & Urostylidae & Tachikawaea gelatinosa & + & Midgut (M4) & Jelly & {$[61]$} \\
\hline & Scutelleridae & Pantoea spp. & + & Midgut (M4) & Egg surface & {$[62]$} \\
\hline \multirow[t]{4}{*}{ Lygaeoidea } & Blissidae & Ischnodemia utricula/Burkholderia spp. & $+/-$ & $\begin{array}{c}\text { Bacteriocyte/Midgut } \\
\text { (M4) }\end{array}$ & $\begin{array}{l}\text { Ovarial } \\
\text { passage/Environment }\end{array}$ & {$[63,64]$} \\
\hline & Artheneidae & Rohrkolberia cinguli & + & Midgut (M1) & Ovarial passage & [65] \\
\hline & Rhyparochromidae & Burkholderia spp. & - & Midgut (M4) & Environment & {$[66]$} \\
\hline & Lygaeidae & $\begin{array}{l}\text { Kleidoceria schneideri/ } \\
\text { Schneideria nysicola, etc. }\end{array}$ & + & Bacteriocyte & Ovarial passage & {$[63,67,68]$} \\
\hline \multirow[t]{3}{*}{ Coreoidea } & Coreidae & Burkholderia spp. & - & Midgut (M4) & Environment & [66] \\
\hline & Alydidae & Burkholderia spp. & - & Midgut (M4) & Environment & [65] \\
\hline & Stenocephalidae & Burkholderia spp. & - & Midgut (M4) & Environment & [69] \\
\hline \multirow[t]{2}{*}{ Pyrrhocoroidea } & Pyrrhocoridae & $\begin{array}{l}\text { Coriobacterium glomerans, } \\
\text { Gordonibacter sp., etc. }\end{array}$ & - & Midgut (M3) & Egg surface & {$[7,70,71]$} \\
\hline & Largidae & Burkholderia spp. & - & Midgut (M4) & Environment & {$[72,73]$} \\
\hline
\end{tabular}

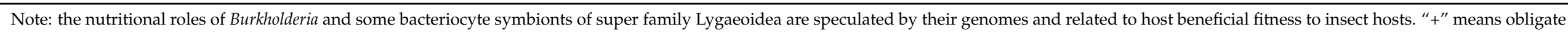
symbiont; "-" means facultative symbiont. The four superfamilies of the stink bugs (Pentatomomorpha) are listed below. 


\subsection{The Intracellular and Extracellular Symbiotic Associations of Heteroptera}

Among the Heteroptera, two infraorders Cimicomorpha and Pentatomomorpha including blood and plant sucking bugs that are universally associated with diverse symbionts. In the Cimicomorpha, the bedbug Cimex lectularius (family Cimicidae) harbors Wolbachia in the bacteriocytes to supply the B vitamins that are devoid in their blood meal but essential for host's growth and reproduction [52,53]. The reduviid bugs Rhodnius prolixus and Triatoma infestans (family Reduviidae) lack bacteriomes and harbor symbiotic Actinobacteria Rhodococcus rhodnii and Nocardia sp. in the anterior midgut regions, e.g., cardia and stomach, are required for the development and survival of the insect hosts [74,75]. Intriguingly, some predatory Mirid bugs (family Miridae) are also associated with Wolbachia and Rickettsia in their bacteriocytes and epithelial cells that may provide nutritional benefits to their hosts (Table 1) [54,55].

Various stinkbugs within the members of infraorder Pentatomomorpha are known as a notorious agricultural pest that damages diverse crop plants worldwide. Unlike the Sternorrhyncha and Auchenorrhyncha, the intestinal bacterial microbiota in the Pentatomomorpha is rather diverse, and the majority of these group insects lack bacteriocytes, only with exception of some Lygaeoidea lineages (Figure 2A). The midgut of stinkbugs has evolved more complex gut morphologies and differentiated into four distinct sections (Figure 1 and Table 1) [7,56-73]. These insects also possess specialized tissue in the posterior region of the midgut (e.g., the midgut fourth section refers to M4, Figure 1) that is morphologically modified into substantial sac-like structures called crypts, in which harbor bacterial symbionts [11,12], and usually, only single bacterial lineage dominates in the M4 crypts for many stinkbug hosts. In Pentatomoidea superfamily, insects do not harbor bacteriocyte symbionts but instead have many different types of obligate gut symbionts (Table 1). Specifically, the Ishikawaella capsulata is associated with plataspid stinkbugs and locate in the M4 of midgut crypts. According to the phylogenetic analysis, this symbiont is the sister group of the aphid obligate symbiont Buchnera, and exhibits AT-biased nucleotide composition and with reduced genome size. Furthermore, these specific gut symbionts are also found to be correlated with the growth, mortality, and sterility of the insect hosts [57]. Collectively, these lines of evidence indicate that the extracellular symbionts are likely to be the obligate partners of the stinkbugs. A variety of obligate gut symbionts are reported in other families of the superfamily Pentatomoidea stinkbugs, such as Tachikawaea gelatinosa in urostylid insects, Pantoea spp. in pentatomid insects, and Rosenkranzia clausaccus in the acanthosomatid insects (Table 1), which are all specifically located in the midgut crypts of each host. In the stinkbugs of the family Scutelleridae, the symbionts were close to the pentatomid gut symbionts of the genus Pantoea is extracellular in the midgut cavity of M4, whereas a facultative symbiont Sodalis sp. is also regularly found in some species associated with the host gonads $[62,76,77]$. Among the stinkbugs, Burkholderia spp. is the most widespread symbiont and extensively found association in M4 crypts of various insect groups in three stinkbugs superfamilies (Lygaeoidea, Coreoidea, and Pyrrhocoroidea) [66,72,78]. Although the Burkholderia symbionts are not strictly obligate with these bug species, these bacteria have been reported to benefit the development, survival, as well as body size and weight of insect hosts, indicating their roles as beneficial mutualists [79].

In addition to crypts of M4 region, the other regions of the midgut are also the habitats for the symbiotic microorganisms in some firebugs and cotton stainers (i.e., family Pyrrhocoridae). These stinkbugs are characterized by the absence of crypts in the M4 region, but instead the substantial gut microbiota is concentrated in the anterior part of midgut section M3, with bacteria cells occurring both attached to the epithelium and free-floating in the host gut lumen [70]. The microbiota mainly consists of Actinobacteria (e.g., Coriobacterium glomerans), Firmicutes (e.g., Clostridium sp.), and Proteobacteria (e.g., Klebsiella sp.). These symbionts are not obligate partners but also play essential roles in host fitness [7,71]. Moreover, the analysis of gut microbiota community structures reveals diverse transient bacterial lineages, such as Brevundimonas, Rhizobium, Pseudomonas, and 
Caulobacter species, residing in the M1, M2, and M4 regions of the pyrrhocorid stinkbug midgut [80].
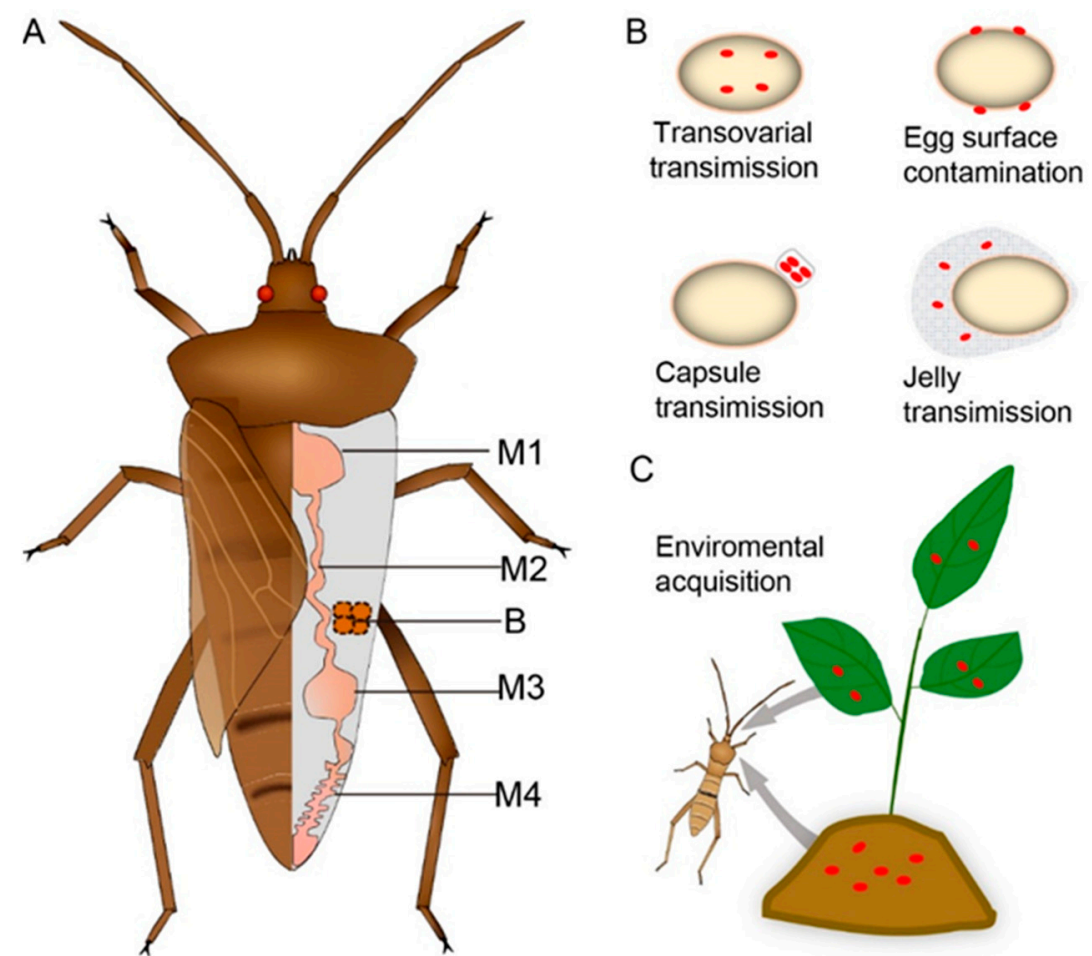

Figure 2. The main transmission routes of symbionts in stinkbugs. (A) schematic stinkbug with symbiotic tissues in an adult insect. M1, midgut first section; M2, midgut second section; M3, midgut third section; M4, midgut fourth section with crypts; B, bacteriomes, dotted line means that bacteriomes are absent in some species. (B) four distinct routes for the vertical transmission of symbionts during the egg stage; (C) the bacterial acquisition from soil or plant material during the nymph stage.

In contrast, the stinkbugs of superfamily Lygaeoidea are atypical groups that have a promiscuous distribution with intracellular or extracellular symbionts. In the family Artheneidae, a stinkbug Chilacis typhae has the enlarged midgut epithelial cells at the end of the M1 section, and the endosymbiont Rohrkolberia cinguli locates in the cytoplasm of the epithelial cells [65]. In addition, the stinkbugs of the family Lygaeidae are harboring endosymbiotic bacteria embedded by specialized bacteriomes. It has been proposed that these species of stinkbugs evolved bacteriome-associated endosymbionts independently through the evolutionary time, such as the symbiont Kleidoceria schneideri in the bacteriome of a birch catkin bug Kleidocerys resedae, the symbiont Rohrkolberia belonochilicola in the bacteriome of Belonochilus numenius, and the symbiont Schneideria nysicola in the bacteriome of Orsillus depressus [63,67]. Regardless of the bacteriome-associated endosymbiont in these group stinkbugs, most lygaeoid and rhyparochromid stinkbugs are consistently associated with extracellular Burkholderia symbionts in the M4 crypts [66]. More interestingly, the stinkbugs of the family Blissidae either harbor the bacteriome-associated symbionts or gut symbionts in M4 crypts. For example, Ischnodemus sabuleti stinkbug is obligately associated with the bacteriocyte-symbionts Ischnodemia utricula, whereas Blissus insularis stinkbug has the Burkholderia in their M4 section [63,64].

\section{The Diverse Strategies of Gut Microbiota Acquisitions in the Stinkbugs}

Stinkbugs have been reported to acquire the gut bacterial microbiota through at least five measures throughout their developmental stages. In general, the gut microbiota may transfer to their offspring either via transovarial transmission during oogenesis, or via the 
exterior of the egg through smearing egg surface, symbiont capsule, and egg jelly during oviposition, or via horizontal acquisitions from the environment during the nymph stage (Figure 2).

\subsection{The Vertical Transmission of the Gut Microbiota in the Stinkbugs}

Transovarial transmission is likely crucial for establishing intracellular microorganisms, as the symbionts use ovarian passage to enter the egg to accomplish their transmission during pre-oviposition (Figure 2B). Although most symbiotic microorganisms are extracellularly associated of the intestine in stinkbugs, the symbiont Rohrkolberia is exceptionally endobiotic in the cytoplasm of midgut epithelial cells locating in the M1 of lygaeid stinkbug C. typhae. The endosymbionts can be transferred to the follicle cells of the germarium and then enter the oocyte cytoplasm, providing strong evidence for transovarial transmission within the egg [65]. The ovarian route of the symbiont transfer occurs in an enclosed environment, within the insect host bodies, facilitating reliable transmission and enable the bacteria to avoid various environmental stresses.

The extracellular symbionts are usually transferred via the exterior of the eggs and then the nymphs acquire the maternal symbionts after hatch. A variety of stinkbugs have been reported that smear their gut symbionts from the anus on the egg surface to accomplish the transfer, particularly among members of superfamily Pentatomoidea and Pyrrhocoroidea (Figure 2B, Table 1). For example, firebugs (the family Pyrrhocoridae) deposit their gut (M3) symbionts Coriobacterium and Gordonibacter sp. from the main tract of midgut to the surface of the eggs during oviposition, consequently followed by newly hatched nymphs probe the egg surface with their proboscis to acquire these symbionts, facilitating the mutual relationships with symbionts between generations [70]. Notably, these bacteria are often detected in the insect feces, indicating a potential transmission route of such symbionts [81]. However, many stinkbugs harbor their symbionts in the crypt cavity of the M4 region instead of the midgut lumen and develop specialized morphological traits of the crypts for their transmission. In the pentatomid stinkbugs, particularly for adult females, several rows of the crypts at the posterior region of the midgut that is morphologically differentiated and conspicuously enlarged, have been found to release the symbiotic bacteria from the crypt cavity to the midgut lumen, thus indicating the insects are able to excrete the symbiotic bacteria from the anus to their egg surface for vertical transmission $[82,83]$. In acanthosomatid stinkbugs, however, the crypts are completely sealed off, and thus block their connection with the midgut lumen, and the female insect develops a pair of peculiar lubrication organs consisting of numerous bacteria-filled tubules associated with the female ovipositor, therefore facilitating the vertical transmission of the gut symbionts to their eggs by surface contamination [60]. In some subsocial stinkbugs, the female adults have the behavior of tending to their offspring after laying eggs, which enhance the transfer of the gut symbionts during oviposition or near the egg hatching stage. In a subsocial stinkbug of family Cydnidae, the female adults also smear symbiont-containing secretions onto eggs upon oviposition as the non-social stinkbugs [84]. However, in another subsocial stinkbug of family Parastrachiidae, the females start to excrete symbiont-containing materials onto the egg mass before egg hatching, and the newborn nymphs immediately ingest the secretion to acquire the symbionts [85]. Thus, these unique styles of symbiont transfer in turn reduce the risks of microbial inactivation by shortening the exposure duration of the bacteria to the environment.

In addition, some stinkbugs do not directly transfer the symbionts on egg surface and instead have exhibited two unique transmission routes: capsule transmission and jelly transmission (Figure 2B). The plataspid stinkbugs deposit sorts of small brownish particles containing symbionts under the egg mass, so-called "symbiont capsules", and then newly hatched nymphs feed on the capsules to ensure the inoculation of gut symbiont Ishikawaella $[86,87]$. The insect reinforces the fidelity of this symbiont transmission via the allocation of the capsule number to egg masses at a ratio of about one symbiont capsule per 3.6 eggs, and the capsules that contain a sufficient amount of symbiont cells, about 
$1.2 \times 10^{8}$ symbionts per capsule [88]. The stinkbugs of the family Urostylididae take another strategy for symbiont transmission, and female adults lay eggs covered with voluminous gut symbiont Tachikawaea mixed with supplemented jelly, followed-by newborn nymphs feed solely on the jelly in midwinter and establish the symbiosis. In these species, their basal regions of ovarioles have evolved into specialized structures producing voluminous translucent liquid embedding the mature oocytes. Meanwhile, a pair of symbiont-filled and female-specific organs consisting of glomerate white tubes are associated with the genital chamber. Thus, the symbionts are mixed in the egg covering gelatinous structure during the oviposition to ensure their survival outside the host body several months during the nymphal growth [61]. Collectively, these diverse strategies of symbionts transfer in stinkbugs facilitate reliable vertical transmission over evolutionary time.

\subsection{The Horizontal Transmission of the Gut Microbiota in the Stinkbugs}

Although vertical transmission appears to be predominant among insect-microbe symbioses, horizontal transmission occurs in some stinkbugs. The Burkholderia symbionts are widespread in substantial lineages within the superfamilies Lygaeoidea, Coreoidea, and Pyrrhocoroidea, and horizontally acquired de novo from the environment by each host generation $[66,79,89]$. The Burkholderia is specifically localized in the midgut crypts of the stinkbugs and does not transmit to eggs. These insects are aposymbiotic in egg and first nymph stages because of the lack of vertical transmission and orally acquire Burkholderia at second instar nymph to establish host-symbiont combinations [89]. Intriguingly, the midgut crypts are rudimentary in the first instar nymph and well-developed in the second instar after oral acquiring the symbiont from the environment, mostly the soils (Figure 2C) [89]. In some largid stinkbugs contain Burkholderia species that is phylogenetically close to the plant-associated group rather than the soil group, and the symbiosis is maintained through the environmental acquisition of the bacteria from plant (Figure 2C) [73]. The selectively inoculations of environmental bacteria are determined both by the specialized structure of the host intestine and the microbial traits $[90,91]$. The stinkbugs develop a specific organ called the "constricted region", a narrow channel connecting the inner cavities of the M3 and M4 sections of the midgut, which form a favorable passage for the symbiont and blockage other bacteria [11,91]. Meanwhile, the specific lipopolysaccharide O-antigen of the symbiontic Burkholderia plays an important role in initialing the symbiotic associations with the host [92], and then the flagella-mediated motility facilitates the migration of Burkholderia through the narrow passage of constricted gut region towards the symbiotic crypt region [93]. Soon afterward, the established symbionts trigger the close of the passage and block potential subsequent infection events [94]. In addition, the symbiotic Burkholderia accumulate granules of polyhydroxyalkanoate within their cells to confer resistance to nutritional depletion and other environmental stresses for their adaptation to symbiotic conditions [95]. These mechanisms for selective accommodation, and maintenance of their specific microbial partners make the Burkholderia horizontal transmission remarkably efficient in Riptortus pedestris, in which few bacterial cells per gram of soil are sufficient for the successful inoculation [96].

The combination of vertical and horizontal transmission also has been found in some stinkbugs. In the Blissidae-Burkholderia symbiosis, the horizontal acquiring is dominated, whereas up to $30 \%$ of the hatchlings vertically acquire symbiotic Burkholderia via egg surfaces [97]. The mixed transmission modes are also found in the symbiosis of pentatomoid stinkbug Plautia stali and the gut symbiont Pantoea spp. The symbionts are primarily vertically transmitted to the egg surface, but some aseptic nymphs also can occasionally acquire suitable free-living Pantoea from soil to replace their obligate roles [98].

\section{Biological Function Roles of Microbial Symbionts in Stinkbugs}

Most stinkbugs are phytophagous insects that have a wide array of symbiotic microorganisms that play important roles in nutritional provision and affect the ecologic fitness and even behavior of their insect hosts in many aspects. 


\subsection{The Nutritional Roles of Gut Symbionts in the Stinkbugs}

Various stinkbugs are specifically associated with obligate symbionts that are essential for the plant-sap feeding insects. Some members of lygaeoid bugs of the families Blissidae are associated with the bacteriocyte symbionts, such as K. schneideri and S. nysicola, which are resembled to Buchnera-aphids symbiosis, with intracellular habitat and co-evolved with host, have the potentials for supplementing nutrition and benefit their host's ecological fitness [63]. In addition, most stinkbugs harbor a variety of gut-associated obligate symbionts that play nutritional roles for insect hosts. In plataspid stinkbugs, the gut symbiont Ishikawaella generally exhibits drastic genome reduction but retains genes that are capable of synthesizing almost all essential amino acids, some vitamins, and other cofactors that are deficient in the plant sap diet. Experimental removal of the symbionts results in slower growth, higher mortality, and sterility of the insects indicating the essential requirement for their hosts $[57,99,100]$. Notably, in an urostylidid stinkbug, the jelly transmitted gut symbiont Tachikawaea provides their host with essential nutrition to benefit offspring's growth and survival [61]. In this symbiosis, the females lay eggs covered with voluminous jelly containing symbiont for vertical transmission. The jelly contains both essential and nonessential amino acids proving the sole food source for newborn nymphs to support nymphal growth and survival until the third instar in the winter season, and then the insects establish the obligate associations with Tachikawaea to supply essential amino acids when they start to feed on plant sap in spring [61]. Similarly, an obligate gut symbiont Rosenkranzia can provide nutrients for fulfilling the development of the acanthosomatid stinkbugs [58].

Pentatomid stinkbugs are generally and obligatorily associated with various bacteria in the genus Pantoea in the crypts of the posterior midgut. Among them, Pantoea carbekii has the potential to provide supplement essential amino acids and vitamins to its herbivorous hosts Halyomorpha halys, thus facilitating their adaptation for a wide range of host plants [101]. However, the effects of the Pantoea species on host biology have strong variations with the different associations with pentatomid stinkbugs. The gut symbiotic bacteria are essential for growth and survival in the green stinkbug Acrosternum hilare, however, the same symbiont has few fitness on the host and is not necessary for development and survival of Murgantia histrionica [102]. The biological roles of the gut symbiont may be different among geographic populations even with the same species. Prado et al. (2006) showed that experimental elimination of the symbiont by sterilizing egg surface and caused few fitness defects in the stinkbug Nezara viridula from the Hawaiian population. The symbiont-free insects have normal growth and reproduction similar to the symbiont-present insects in two experiential generations [83]. Whereas, experimental sterilization of the symbiont resulted in severe nymphal mortality for the Japanese population, indicating an obligate host-symbiont relationship [103]. In another pentatomid stinkbug Plautia stali, different original populations harbor the obligate symbionts Pantoea spp. of several distinct bacterial lineages, including both the uncultivable and cultivable lineages. These symbionts are indispensable for normal host growth and survival, and the sterile newborns can acquire the cultivable symbionts from environmental soils to restore normal growth [98]. Collectively, the Pantoea lineages are likely to be an ongoing evolutionary transition from a free-living lifestyle to facultative and obligate mutualism in the pentatomid stinkbugs. The family of Scutelleridae has obligate associations with the gut symbiont Pantoea sp. that provides essential roles for insect host survival $[76,77]$.

In addition, the parastrachiid stinkbug Parastrachia japonensis has a prolonged (10 months to 2 years) non-feeding diapause at the adult stage, the presence of gut Benitsuchiphilus tojoi involve in the supplement of amino acids and vitamins and also have a key role in the recycling of uric acid to aid the host survival the long-term diapause [59,60]. In addition, the symbiont also contains a plasmid encoding genes for thiamine and carotenoid synthesis pathways, which may give the symbiont additional roles in protecting the host against oxidative stress and DNA damage [104]. 
Some facultative symbionts also have nutritional benefits for their hosts, establishing the important microbes with stinkbugs. In some pyrrhocorid stinkbugs, M3 region of midgut with diverse microbiota includes actinobacterial symbionts (e.g., Coriobacterium and Gordonibacter sp.) or Firmicutes (e.g., Clostridium sp. and Lactococcus sp.), and these symbionts essentially affect the survival and growth of their hosts [71,105]. Further study indicates the gut actinobacterial symbionts could also provide B vitamins to their hosts that are scarce in the diet and enhance hosts' fitness [7]. The vitamin-supplementing symbionts also facilitate their hosts' adaptation on the plants, and the acquisition of core microbiota enable these insects to be generalist and expand food source to the nutritionally imbalanced and chemically well-defended seeds of Malvales plants [106]. Although the common stinkbug symbiont Burkholderia is not strictly obligate and essential for the hosts, several studies show that removal of the symbiont could lead to slower development, lower survival rate, and reduced body weight and size of insect hosts. Moreover, transcriptomic data show the symbionts produced all essential amino acids and B vitamins that are scarce in the host food indicating a nutritional benefit provided by these symbionts $[66,79,107]$.

\subsection{The Other Ecological Roles of Symbionts in Stinkbugs}

In addition to nutritional roles, the gut symbionts may influence the other ecological traits on their hosts, which provide insights into their roles in ecology and adaptation of the insects. The Burkholderia are widely found to been capable of insecticide-degradation in the environments and confer the bean bug $R$. pedestris insecticide resistance [13]. The applications of insecticide fenitrothion to agricultural field soils drastically enrich fenitrothiondegrading Burkholderia, and the stinkbugs acquire the bacteria from soil during larval development and harbor them in a posterior region of the midgut, resulted in the host with the strong capacity of insecticide resistance $[108,109]$. The acquisition of Burkholderia also effects various aspects of host physiology, including juvenile hormone and the innate immunity, enhancing the reproduction and growth of the insect hosts [110-112]. On one hand, the symbiotic Burkholderia has a drastic change of bacterial cell envelope that suppresses the immune responses of the symbiotic midgut to prosper the bacteria in their hosts [112]. On the other hand, the inoculation of Burkhoderia positively affects the host's systematic immunity by increasing hemolymph antimicrobial activity and antimicrobial peptide expression in the symbiont-present insects to confer the host better survival [113]. Further, the colonization of Burkholderia gut symbiont in the insect also modulate the titer of specific juvenile hormone by increasing the hexamerin- $\alpha$ and vitellogenin proteins in the hemolymph, thus enhancing the reproduction and growth of the hosts $[110,114]$.

Some gut symbionts promote the host behavioral alterations in stinkbugs. In a plataspid bug Megacopta punctatissima, newborn nymphs often aggregate and are quiescent after acquiring the gut symbiont Ishikawaella from the capsule, whereas these insects keep wandering once the failure of inoculating the symbiont [115]. Genomic analysis also reveals that the symbionts containing a gene encoded for arginine metabolism and oxalate detoxification, and the oxalate-catalyzing enzymes may potentially detoxify plant oxalate to provide a highly adaptive benefits for their insect host $[99,116]$. Furthermore, the symbionts have been found correlated with the pest status of the insect hosts. Two phylogenetically closely related plataspid stinkbugs, the pest $M$. punctatissima and the non-pest species $M$. cribraria, their pest status on crop legumes are determined by obligate gut symbiont Ishikawaella rather than the insect genotype. The exchange of their obligate gut symbionts leads to the reverse of their performance on the crop and pest status [117].

\section{The Stinkbugs-Gut Microbiota Associations as Targets and Models for Agricultural Pest Control Applications}

The insect microbiota has been exploited as targets for pest control, either as delivery agents of insecticide, or use to suppress insect vector competence [118,119]. The major innovation in insect microbiota as the target is to replace the current broad-spectrum chemical insecticides. A recent study of Wolbachia inoculations in rice pest brown planthopper has been showed high levels of cytoplasmic incompatibility by reducing the uninfected pest 
populations and inhibited the transmission of "Rice ragged stunt virus" [120]. In addition, engineering the bacterial symbionts represents another breakthrough in pest control, which has been demonstrated to efficient in both western corn rootworms [121] and honeybee parasitic mites [122]. However, the vast majority of gut microbial symbionts remains unexplored, indicating that the vast majority of the targets also remain untouched-all with promising potential for pest control applications.

Agricultural pests that damage a variety of crop plants globally, particular the stinkbugs cause severe economic impacts on cotton and bean field. The beneficial gut microbial symbionts to enhance the host fitness is not a unique phenomenon of stinkbugs [123,124] but appears to be shared across most agricultural insects. The studies of stinkbug gut microbiota will greatly expand the current well-studied insect-gut microbiota models including Drosophila, honeybee, and termite [125-127]. In many aspects, the stinkbugs-gut microbiota is valuable to investigate the biological and molecular interactions between host and microbes. In the pyrrhocorid, pentatomid, and plataspid bugs, their gut symbionts are transferred outside during the vertical transmission, and the aposymbiotic and re-inoculation experiments are easily established to analyze their various physiological aspects of hosts, including growth, behavior, metabolism, etc. [7,17,62,71,87]. On the other hand, the obligate partners are essential or important for host survival, development or fecundity, indicating the symbionts may serve as targets for pest control and therefore the disruption of these microbial associations would lead to low vitality of the pest [128]. Specifically, the change of the obligate gut symbionts for a plataspid stinkbug will reverse the pest M. punctatissima to be a non-pest status on the legumes crop, indicating the potential microbial targets for pest control [117]. In addition, sorts of gut bacteria have transit stages from free-living to symbiotic, culturable under laboratory conditions, and genetically manipulatable $[129,130]$. The experimental and genetic tractability of Burkholderia in the bean bug $R$. pedestris is a valuable model for engineering the bacterial symbiont as delivery agents of insecticide, similar to the engineered bacterial symbionts in western corn rootworm [121] and honeybee [122], to explore the novel strategy for pest management. Collectively, these features symbiosis in stinkbugs provide the potential models for agricultural pest biocontrol.

Author Contributions: Conceptualization, H.S., W.W., and H.L.; writing original draft preparation, H.S.; writing, review and editing, H.S., W.W., Z.S., J.C., and H.L. All authors have read and agreed to the published version of the manuscript.

Funding: This work was supported by the National Transgenic Science and Technology Program (2019ZX08004-004), and the Natural Science Foundation of Zhejiang Province, China (LQ21C140003).

Institutional Review Board Statement: Not applicable.

Informed Consent Statement: Not applicable.

Data Availability Statement: Not applicable.

Conflicts of Interest: The authors declare no conflict of interest.

\section{References}

1. Jiang, Y.; Zhang, C.X.; Chen, R.; He, S.Y. Challenging battles of plants with phloem-feeding insects and prokaryotic pathogens. Proc. Natl. Acad. Sci. USA 2019, 47, 23390-23397. [CrossRef]

2. Navas-Castillo, J.; Fiallo-Olivé, E.; Sánchez-Campos, S. Emerging virus diseases transmitted by whiteflies. Annu. Rev. Phytopathol. 2011, 49, 219-248. [CrossRef]

3. Kriticos, D.J.; Kean, J.M.; Phillips, C.B.; Senay, S.D.; Acosta, H.; Haye, T. The potential global distribution of the brown marmorated stink bug, Halyomorpha halys, a critical threat to plant biosecurity. J. Pest. Sci. 2017, 90, 1033-1043. [CrossRef]

4. Dhammi, A.; van Krestchmar, J.B.; Ponnusamy, L.; Bacheler, J.S.; Reisig, D.D.; Herbert, A.; Del Pozo-Valdivia, A.I.; Roe, R.M. Biology, pest status, microbiome and control of kudzu bug (Hemiptera: Heteroptera: Plataspidae): A new invasive pest in the U.S. Int. J. Mol. Sci. 2016, 17, 1570. [CrossRef]

5. Douglas, A. Nutritional interactions in insect-microbial symbioses: Aphids and their symbiotic bacteria Buchnera. Annu. Rev. Entomol. 1998, 43, 17-37. [CrossRef] [PubMed] 
6. Sudakaran, S.; Kost, C.; Kaltenpoth, M. Symbiont acquisition and replacement as a source of ecological innovation. Trends Microbiol. 2017, 25, 375-390. [CrossRef] [PubMed]

7. Salem, H.; Bauer, E.; Strauss, A.S.; Vogel, H.; Marz, M.; Kaltenpoth, M. Vitamin supplementation by gut symbionts ensures metabolic homeostasis in an insect host. Proc. R. Soc. B 2014, 281, 20141838. [CrossRef]

8. Engel, P.; Moran, N.A. The gut microbiota of insects-diversity in structure and function. FEMS Microbiol. Rev. 2013, 37, 699-735. [CrossRef] [PubMed]

9. Douglas, A. Mycetocyte symbiosis in insects. Biol. Rev. 1989, 64, 409-434. [CrossRef]

10. Baumann, P. Biology of bacteriocyte-associated endosymbionts of plant sap-sucking insects. Annu. Rev. Microbiol. 2005, 59, 155-189. [CrossRef] [PubMed]

11. Ohbayashi, T.; Takeshita, K.; Kitagawa, W.; Nikoh, N.; Koga, R.; Meng, X.Y.; Tago, K.; Hori, T.; Hayatsu, M.; Asano, K.; et al. Insect's intestinal organ for symbiont sorting. Proc. Natl. Acad. Sci. USA 2015, 112, E5179-E5188. [CrossRef]

12. Oishi, S.; Moriyama, M.; Koga, R.; Fukatsu, T. Morphogenesis and development of midgut symbiotic organ of the stinkbug Plautia stali (Hemiptera: Pentatomidae). Zool. Lett. 2019, 5, 16. [CrossRef]

13. Kikuchi, Y.; Hayatsu, M.; Hosokawa, T.; Nagayama, A.; Tago, K.; Fukatsu, T. Symbiont-mediated insecticide resistance. Proc. Natl. Acad. Sci. USA 2012, 109, 8618. [CrossRef] [PubMed]

14. Oliver, K.M.; Degnan, P.H.; Burke, G.R.; Moran, N.A. Facultative symbionts in aphids and the horizontal transfer of ecologically important traits. Annual. Rev. Entomol. 2010, 55, 247-266. [CrossRef] [PubMed]

15. Montllor, C.B.; Maxmen, A.; Purcell, A.H. Facultative bacterial endosymbionts benefit pea aphids Acyrthosiphon pisum under heat stress. Ecol. Entomol. 2002, 27, 189-195. [CrossRef]

16. Feldhaar, H. Bacterial symbionts as mediators of ecologically important traits of insect hosts. Ecol. Entomol. 2011, 36, 533-543. [CrossRef]

17. Salem, H.; Florez, L.; Gerardo, N.; Kaltenpoth, M. An out-of-body experience: The extracellular dimension for the transmission of mutualistic bacteria in insects. Proc. R. Soc. B 2015, 282, 20142957. [CrossRef]

18. Li, H.; Leavengood, J.M., Jr.; Chapman, E.G.; Burkhardt, D.; Song, F.; Jiang, P.; Liu, J.; Zhou, X.; Cai, W. Mitochondrial phylogenomics of Hemiptera reveals adaptive innovations driving the diversification of true bugs. Proc. R. Soc. B 2017, 284, 20171223. [CrossRef]

19. Thao, M.L.; Moran, N.A.; Abbot, P.; Brennan, E.B.; Burckhardt, D.H.; Baumann, P. Cospeciation of psyllids and their primary prokaryotic endosymbionts. Appl. Environ. Microbiol. 2000, 66, 2898-2905. [CrossRef]

20. Thao, M.L.; Baumann, P. Evolutionary relationships of primary prokaryotic endosymbionts of whiteflies and their hosts. Appl. Environ. Microbiol. 2004, 70, 3401-3406. [CrossRef]

21. Shigenobu, S.; Watanabe, H.; Hattori, M.; Sakaki, Y.; Ishikawa, H. Genome sequence of the endocellular bacterial symbiont of aphids Buchnera sp. APS. Nature 2000, 407, 81-86. [CrossRef] [PubMed]

22. Munson, M.A.; Baumann, P.; Moran, N.A. Phylogenetic relationships of the endosymbionts of mealybugs (Homoptera: Pseudococcidae) based on 16S rDNA sequences. Mol. Phylogenet. Evol. 1992, 1, 26-30. [CrossRef]

23. Moran, N.A.; Dale, C.; Dunbar, H.; Smith, W.A.; Ochman, H. Intracellular symbionts of sharpshooters (Insecta: Hemiptera: Cicadellinae) form a distinct clade with a small genome. Environ. Microbiol. 2003, 5, 116-126. [CrossRef] [PubMed]

24. Wu, D.; Daugherty, S.C.; Van Aken, S.E.; Pai, G.H.; Watkins, K.L.; Khouri, H.; Tallon, L.J.; Zaborsky, J.M.; Dunbar, H.E.; Tran, P.L.; et al. Metabolic complementarity and genomics of the dual bacterial symbiosis of sharpshooters. PLoS Biol. 2006, 4, e188. [CrossRef]

25. McCutcheon, J.P.; McDonald, B.R.; Moran, N.A. Convergent evolution of metabolic roles in bacterial co-symbionts of insects. Proc. Natl. Acad. Sci. USA 2009, 106, 15394-15399. [CrossRef] [PubMed]

26. Mao, M.; Yang, X.; Poff, K.; Bennett, G. Comparative genomics of the dual-obligate symbionts from the treehopper, Entylia carinata (Hemiptera: Membracidae), provide insight into the origins and evolution of an ancientsymbiosis. Genome Biol. Evol. 2017, 9, 1803-1815. [CrossRef]

27. McCutcheon, J.P.; Moran, N.A. Functional convergence in reduced genomes of bacterial symbionts spanning $200 \mathrm{My}$ of evolution. Genome Biol. Evol. 2010, 2, 708-718. [CrossRef] [PubMed]

28. Sasaki, T.; Kawamura, M.; Ishikawa, H. Nitrogen recycling in the brown planthopper, Nilaparvata lugens: Involvement of yeast-like endosymbionts in uric acid metabolism. J. Insect Physiol. 1996, 42, 125-129. [CrossRef]

29. Urban, J.M.; Cryan, J.R. Two ancient bacterial endosymbionts have coevolved with the planthoppers (Insecta: Hemiptera: Fulgoroidea). BMC Evol. Biol. 2012, 12, 87. [CrossRef]

30. Braendle, C.; Miura, T.; Bickel, R.; Shingleton, A.W.; Kambhampati, S.; Stern, D.L. Developmental origin and evolution of bacteriocytes in the aphid-Buchnera symbiosis. PLoS Biol. 2003, 1, e21. [CrossRef]

31. Koga, R.; Meng, X.Y.; Tsuchida, T.; Fukatsu, T. Cellular mechanism for selective vertical transmission of an obligate insect symbiont at the bacteriocyte-embryo interface. Proc. Natl. Acad. Sci. USA 2012, 109, E1230-E1237. [CrossRef] [PubMed]

32. Moran, N.A.; McCutcheon, J.P.; Nakabachi, A. Genomics and evolution of heritable bacterial symbionts. Annu. Rev.Genet. 2008, 42, 165-190. [CrossRef] [PubMed]

33. Moran, N.A.; Bennett, G.M. The tiniest tiny genomes. Annu. Rev. Microbiol. 2014, 68, 195-215. [CrossRef]

34. Fukatsu, T.; Ishikawa, H. Phylogenetic position of yeast-like symbiont of Hamiltonaphis styraci (homoptera, aphididae) based on $18 \mathrm{~S}$ rDNA sequence. Insect Biochem. Mol. Biol. 1996, 26, 383-388. [CrossRef] 
35. Leonardo, T.E. Removal of a specialization-associated symbiont does not affect aphid fitness. Ecol. Lett. 2004, 7, 461-468. [CrossRef]

36. Leonardo, T.E.; Muiru, G.T. Facultative symbionts are associated with host plant specialization in pea aphid populations. Proc. R. Soc. B 2003, 270, S209-S212. [CrossRef] [PubMed]

37. Costa, H.; Westcot, D.; Ullman, D.; Johnson, M.J.P. Ultrastructure of the endosymbionts of the whitefly, Bemisia tabaci and Trialeurodes vaporariorum. Protoplasma 1993, 176, 106-115. [CrossRef]

38. Luan, J.B.; Shan, H.W.; Isermann, P.; Huang, J.H.; Lammerding, J.; Liu, S.S.; Douglas, A.E. Cellular and molecular remodelling of a host cell for vertical transmission of bacterial symbionts. Proc. R. Soc. B 2016, 283, 20160580. [CrossRef]

39. Szklarzewicz, T.; Moskal, A. Ultrastructure, distribution, and transmission of endosymbionts in the whitefly Aleurochiton aceris Modeer (Insecta, Hemiptera, Aleyrodinea). Protoplasma 2001, 218, 45-53. [CrossRef] [PubMed]

40. Skaljac, M.; Zanic, K.; Ban, S.G.; Kontsedalov, S.; Ghanim, M. Co-infection and localization of secondary symbionts in two whitefly species. BMC Microbiol. 2010, 10, 142. [CrossRef] [PubMed]

41. Santos-Garcia, D.; Juravel, K.; Freilich, S.; Zchori-Fein, E.; Latorre, A.; Moya, A.; Morin, S.; Silva, F.J. To B or not to B: Comparative genomics suggests Arsenophonus as a source of B vitamins in whiteflies. Front. Microbiol. 2018, 9, 2254. [CrossRef] [PubMed]

42. Luan, J.B.; Chen, W.; Hasegawa, D.K.; Simmons, A.M.; Wintermantel, W.M.; Ling, K.S.; Fei, Z.; Liu, S.S.; Douglas, A.E. Metabolic coevolution in the bacterial symbiosis of whiteflies and related plant sap-feeding insects. Genome Biol. Evol. 2015, 7, $2635-2647$. [CrossRef] [PubMed]

43. Shan, H.; Liu, Y.; Luan, J.; Liu, S. New insights into the transovarial transmission of the symbiont Rickettsia in whiteflies. Sci China Life Sci. 2020. [CrossRef] [PubMed]

44. Brumin, M.; Levy, M.; Ghanim, M. Transovarial transmission of Rickettsia spp. and organ-specific infection of the whitefly Bemisia tabaci. Appl. Environ. Microbiol. 2012, 78, 5565-5574. [CrossRef] [PubMed]

45. Wang, H.L.; Lei, T.; Wang, X.W.; Maruthi, M.N.; Zhu, D.T.; Cameron, S.L.; Rao, Q.; Shan, H.W.; Colvin, J.; Liu, Y.Q.; et al. A newly recorded Rickettsia of the Torix group is a recent intruder and an endosymbiont in the whitefly Bemisia tabaci. Environ. Microbiol. 2020, 22, 1207-1221. [CrossRef]

46. Jing, X.; Wong, A.C.; Chaston, J.M.; Colvin, J.; McKenzie, C.L.; Douglas, A.E. The bacterial communities in plant phloem-sapfeeding insects. Mol. Ecol. 2014, 23, 1433-1444. [CrossRef]

47. Mao, M.; Yang, X.; Bennett, G.M. Evolution of host support for two ancient bacterial symbionts with differentially degraded genomes in a leafhopper host. Proc. Natl. Acad. Sci. USA 2018, 115, E11691-E11700. [CrossRef] [PubMed]

48. Bennett, G.M.; Moran, N.A. Small, smaller, smallest: The origins and evolution of ancient dual symbioses in a Phloem-feeding insect. Genome Biol. Evol. 2013, 5, 1675-1688. [CrossRef]

49. Nishino, T.; Tanahashi, M.; Lin, C.P.; Koga, R.; Fukatsu, T. Fungal and bacterial endosymbionts of eared leafhoppers of the subfamily Ledrinae (Hemiptera: Cicadellidae). Appl. Entomol. Zool. 2016, 51, 465-477. [CrossRef]

50. Sacchi, L.; Genchi, M.; Clementi, E.; Bigliardi, E.; Avanzati, A.M.; Pajoro, M.; Negri, I.; Marzorati, M.; Gonella, E.; Alma, A.; et al Multiple symbiosis in the leafhopper Scaphoideus titanus (Hemiptera: Cicadellidae): Details of transovarial transmission of Cardinium sp. and yeast-like endosymbionts. Tissue Cell 2008, 40, 231-242. [CrossRef]

51. Ju, J.F.; Bing, X.L.; Zhao, D.S.; Guo, Y.; Xi, Z.; Hoffmann, A.A.; Zhang, K.J.; Huang, H.J.; Gong, J.T.; Zhang, X.; et al. Wolbachia supplement biotin and riboflavin to enhance reproduction in planthoppers. ISME J. 2019, 14, 676-687. [CrossRef] [PubMed]

52. Hosokawa, T.; Koga, R.; Kikuchi, Y.; Meng, X.Y.; Fukatsu, T. Wolbachia as a bacteriocyte-associated nutritional mutualist. Proc. Natl. Acad. Sci. USA 2010, 107, 769-774. [CrossRef] [PubMed]

53. Nikoh, N.; Hosokawa, T.; Moriyama, M.; Oshima, K.; Hattori, M.; Fukatsu, T. Evolutionary origin of insect-Wolbachia nutritional mutualism. Proc. Natl. Acad. Sci. USA 2014, 111, 10257-10262. [CrossRef] [PubMed]

54. Dally, M.; Lalzar, M.; Belausov, E.; Gottlieb, Y.; Coll, M.; Zchori-Fein, E. Cellular localization of two Rickettsia symbionts in the digestive system and within the ovaries of the Mirid bug, Macrolophous Pygmaeus. Insects 2020, 11, 530. [CrossRef] [PubMed]

55. Caspi-Fluger, A.; Inbar, M.; Steinberg, S.; Friedmann, Y.; Freund, M.; Mozes-Daube, N.; Zchori-Fein, E. Characterization of the symbiont Rickettsia in the mirid bug Nesidiocoris tenuis (Reuter) (Heteroptera: Miridae). Bull. Entomol. Res. 2014, 104, 681-688. [CrossRef]

56. Bansal, R.; Michel, A.P.; Sabree, Z.L. The crypt-dwelling primary bacterial symbiont of the polyphagous pentatomid pest Halyomorpha halys (Hemiptera: Pentatomidae). Environ. Entomol. 2014, 43, 617-625. [CrossRef]

57. Hosokawa, T.; Kikuchi, Y.; Nikoh, N.; Shimada, M.; Fukatsu, T. Strict host-symbiont cospeciation and reductive genome evolution in insect gut bacteria. PLoS Biol. 2006, 4, e337. [CrossRef]

58. Kashima, T.; Nakamura, T.; Tojo, S. Uric acid recycling in the shield bug, Parastrachia japonensis (Hemiptera: Parastrachiidae), during diapause. J. Insect. Physiol. 2006, 52, 816-825. [CrossRef]

59. Hosokawa, T.; Kikuchi, Y.; Nikoh, N.; Meng, X.Y.; Hironaka, M.; Fukatsu, T. Phylogenetic position and peculiar genetic traits of a midgut bacterial symbiont of the stinkbug Parastrachia japonensis. Appl. Environ. Microbiol. 2010, 76, 4130-4135. [CrossRef] [PubMed]

60. Kikuchi, Y.; Hosokawa, T.; Nikoh, N.; Meng, X.Y.; Kamagata, Y.; Fukatsu, T. Host-symbiont co-speciation and reductive genome evolution in gut symbiotic bacteria of acanthosomatid stinkbugs. BMC Biol. 2009, 7, 2. [CrossRef] 
61. Kaiwa, N.; Hosokawa, T.; Nikoh, N.; Tanahashi, M.; Moriyama, M.; Meng, X.Y.; Maeda, T.; Yamaguchi, K.; Shigenobu, S.; Ito, M.; et al. Symbiont-supplemented maternal investment underpinning host's ecological adaptation. Curr. Biol. 2014, 24, $2465-2470$. [CrossRef]

62. Kaiwa, N.; Hosokawa, T.; Kikuchi, Y.; Nikoh, N.; Meng, X.Y.; Kimura, N.; Ito, M.; Fukatsu, T. Primary gut symbiont and secondary, Sodalis-allied symbiont of the Scutellerid stinkbug Cantao ocellatus. Appl. Environ. Microbiol. 2010, 76, 3486-3494. [CrossRef] [PubMed]

63. Kuechler, S.M.; Renz, P.; Dettner, K.; Kehl, S. Diversity of symbiotic organs and bacterial endosymbionts of lygaeoid bugs of the families blissidae and lygaeidae (hemiptera: Heteroptera: Lygaeoidea). Appl. Environ. Microbiol. 2012, 78, 2648-2659. [CrossRef]

64. Boucias, D.G.; Garcia-Maruniak, A.; Cherry, R.; Lu, H.; Maruniak, J.E.; Lietze, V.U. Detection and characterization of bacterial symbionts in the Heteropteran, Blissus insularis. FEMS Microbiol. Ecol. 2012, 82, 629-641. [CrossRef] [PubMed]

65. Kuechler, S.M.; Dettner, K.; Kehl, S. Characterization of an obligate intracellular bacterium in the midgut epithelium of the bulrush bug Chilacis typhae (Heteroptera, Lygaeidae, Artheneinae). Appl. Environ. Microbiol. 2011, 77, 2869-2876. [CrossRef]

66. Kikuchi, Y.; Hosokawa, T.; Fukatsu, T. An ancient but promiscuous host-symbiont association between Burkholderia gut symbionts and their heteropteran hosts. ISME J. 2011, 5, 446-460. [CrossRef] [PubMed]

67. Matsuura, Y.; Kikuchi, Y.; Hosokawa, T.; Koga, R.; Meng, X.Y.; Kamagata, Y.; Nikoh, N.; Fukatsu, T. Evolution of symbiotic organs and endosymbionts in lygaeid stinkbugs. ISME J. 2012, 6, 397-409. [CrossRef] [PubMed]

68. Küchler, S.M.; Dettner, K.; Kehl, S. Molecular characterization and localization of the obligate endosymbiotic bacterium in the birch catkin bug Kleidocerys resedae (Heteroptera: Lygaeidae, Ischnorhynchinae). FEMS Microbiol. Ecol. 2010, 73, 408-418. [CrossRef] [PubMed]

69. Kuechler, S.M.; Matsuura, Y.; Dettner, K.; Kikuchi, Y. Phylogenetically diverse Burkholderia associated with midgut crypts of spurge bugs, Dicranocephalus spp. (Heteroptera: Stenocephalidae). Microbes Environ. 2016, 31, 145-153. [CrossRef] [PubMed]

70. Kaltenpoth, M.; Winter, S.A.; Kleinhammer, A. Localization and transmission route of Coriobacterium glomerans, the endosymbiont of pyrrhocorid bugs. FEMS Microbiol. Ecol. 2009, 69, 373-383. [CrossRef] [PubMed]

71. Salem, H.; Kreutzer, E.; Sudakaran, S.; Kaltenpoth, M. Actinobacteria as essential symbionts in firebugs and cotton stainers (Hemiptera, Pyrrhocoridae). Environ. Microbiol. 2013, 15, 1956-1968. [CrossRef] [PubMed]

72. Takeshita, K.; Matsuura, Y.; Itoh, H.; Navarro, R.; Hori, T.; Sone, T.; Kamagata, Y.; Mergaert, P.; Kikuchi, Y. Burkholderia of plant-beneficial group are symbiotically associated with bordered plant bugs (Heteroptera: Pyrrhocoroidea: Largidae). Microbes Environ. 2015, 30, 321-329. [CrossRef] [PubMed]

73. Gordon, E.R.; McFrederick, Q.; Weirauch, C. Phylogenetic evidence for ancient and persistent environmental symbiont reacquisition in Largidae (Hemiptera: Heteroptera). Appl. Environ. Microbiol. 2016, 82, 7123-7133. [CrossRef]

74. Eichler, S.; Schaub, G.A. Development of symbionts in triatomine bugs and the effects of infections with trypanosomatids. Exp. Parasitol. 2002, 100, 17-27. [CrossRef] [PubMed]

75. Salcedo-Porras, N.; Umana-Diaz, C.; Bitencourt, R.O.B.; Lowenberger, C. The role of bacterial symbionts in Triatomines: An evolutionary perspective. Microorganisms 2020, 8, 1438. [CrossRef] [PubMed]

76. Kaiwa, N.; Hosokawa, T.; Kikuchi, Y.; Nikoh, N.; Meng, X.Y.; Kimura, N.; Ito, M.; Fukatsu, T. Bacterial symbionts of the giant jewel stinkbug Eucorysses grandis (Hemiptera: Scutelleridae). Zool. Sci. 2011, 28, 169-174. [CrossRef] [PubMed]

77. Hosokawa, T.; Imanishi, M.; Koga, R.; Fukatsu, T. Diversity and evolution of bacterial symbionts in the gut symbiotic organ of jewel stinkbugs (Hemiptera: Scutelleridae). Appl. Entomol. Zool. 2019, 54, 359-367. [CrossRef]

78. Garcia, J.R.; Laughton, A.M.; Malik, Z.; Parker, B.J.; Trincot, C.; Chiang, S.S.L.; Chung, E.; Gerardo, N.M. Partner associations across sympatric broad-headed bug species and their environmentally acquired bacterial symbionts. Mol. Ecol. 2014, 23, 1333-1347. [CrossRef]

79. Kikuchi, Y.; Hosokawa, T.; Fukatsu, T. Insect-microbe mutualism without vertical transmission: A stinkbug acquires a beneficial gut symbiont from the environment every generation. Appl. Environ. Microbiol. 2007, 73, 4308-4316. [CrossRef]

80. Sudakaran, S.; Salem, H.; Kost, C.; Kaltenpoth, M. Geographical and ecological stability of the symbiotic mid-gut microbiota in European firebugs, Pyrrhocoris apterus (Hemiptera, Pyrrhocoridae). Mol. Ecol. 2012, 21, 6134-6151. [CrossRef] [PubMed]

81. Salem, H.; Onchuru, T.O.; Bauer, E.; Kaltenpoth, M. Symbiont transmission entails the risk of parasite infection. Biol. Lett. 2015, 11, 20150840. [CrossRef]

82. Hayashi, T.; Hosokawa, T.; Meng, X.Y.; Koga, R.; Fukatsu, T. Female-specific specialization of a posterior end region of the midgut symbiotic organ in Plautia splendens and allied stinkbugs. Appl. Environ. Microbiol. 2015, 81, 2603-2611. [CrossRef]

83. Prado, S.S.; Rubinoff, D.; Almeida, R.P.P. Vertical transmission of a Pentatomid caeca-associated symbiont. Ann. Entomol. Soc. Am. 2006, 99, 577-585. [CrossRef]

84. Hosokawa, T.; Hironaka, M.; Inadomi, K.; Mukai, H.; Nikoh, N.; Fukatsu, T. Diverse strategies for vertical symbiont transmission among subsocial stinkbugs. PLoS ONE 2013, 8, e65081. [CrossRef] [PubMed]

85. Hosokawa, T.; Hironaka, M.; Mukai, H.; Inadomi, K.; Suzuki, N.; Fukatsu, T. Mothers never miss the moment: A fine-tuned mechanism for vertical symbiont transmission in a subsocial insect. Anim. Behav. 2012, 83, 293-300. [CrossRef]

86. Hosokawa, T.; Fukatsu, T. Relevance of microbial symbiosis to insect behavior. Curr. Opin. Insect Sci. 2020, 39, 91-100. [CrossRef] [PubMed]

87. Fukatsu, T.; Hosokawa, T. Capsule-transmitted gut symbiotic bacterium of the Japanese common Plataspid stinkbug, Megacopta punctatissima. Appl. Environ. Microbiol. 2002, 68, 389-396. [CrossRef] 
88. Hosokawa, T.; Kikuchi, Y.; Fukatsu, T. How many symbionts are provided by mothers, acquired by offspring, and needed for successful vertical transmission in an obligate insect-bacterium mutualism? Mol. Ecol. 2007, 16, 5316-5325. [CrossRef]

89. Kikuchi, Y.; Hosokawa, T.; Fukatsu, T. Specific developmental window for establishment of an insect-microbe gut symbiosis. Appl. Environ. Microbiol. 2011, 77, 4075-4081. [CrossRef] [PubMed]

90. Kim, J.K.; Lee, B.L. Symbiotic factors in Burkholderia essential for establishing an association with the bean bug, Riptortus pedestris. Arch. Insect Biochem. Physiol. 2015, 88, 4-17. [CrossRef]

91. Kim, J.K.; Kim, N.H.; Jang, H.A.; Kikuchi, Y.; Kim, C.H.; Fukatsu, T.; Lee, B.L. Specific midgut region controlling the symbiont population in an insect-microbe gut symbiotic association. Appl. Environ. Microbiol. 2013, 79, 7229-7233. [CrossRef]

92. Kim, J.K.; Park, H.Y.; Lee, B.L. The symbiotic role of O-antigen of Burkholderia symbiont in association with host Riptortus pedestris. Dev. Comp. Immunol. 2016, 60, 202-208. [CrossRef] [PubMed]

93. Kinosita, Y.; Kikuchi, Y.; Mikami, N.; Nakane, D.; Nishizaka, T. Unforeseen swimming and gliding mode of an insect gut symbiont, Burkholderia sp. RPE64, with wrapping of the flagella around its cell body. ISME J. 2018, 12, 838-848. [CrossRef] [PubMed]

94. Kikuchi, Y.; Ohbayashi, T.; Jang, S.; Mergaert, P. Burkholderia insecticola triggers midgut closure in the bean bug Riptortus pedestris to prevent secondary bacterial infections of midgut crypts. ISME J. 2020, 14, 1627-1638. [CrossRef] [PubMed]

95. Kim, J.K.; Won, Y.J.; Nikoh, N.; Nakayama, H.; Han, S.H.; Kikuchi, Y.; Rhee, Y.H.; Park, H.Y.; Kwon, J.Y.; Kurokawa, K.; et al. Polyester synthesis genes associated with stress resistance are involved in an insect-bacterium symbiosis. Proc. Natl. Acad. Sci. USA 2013, 110, E2381-E2389. [CrossRef]

96. Kikuchi, Y.; Yumoto, I. Efficient colonization of the bean bug Riptortus pedestris by an environmentally transmitted Burkholderia symbiont. Appl. Environ. Microbiol. 2013, 79, 2088-2091. [CrossRef]

97. Itoh, H.; Aita, M.; Nagayama, A.; Meng, X.Y.; Kamagata, Y.; Navarro, R.; Hori, T.; Ohgiya, S.; Kikuchi, Y. Evidence of environmental and vertical transmission of Burkholderia symbionts in the oriental chinch bug, Cavelerius saccharivorus (Heteroptera: Blissidae). Appl. Environ. Microbiol. 2014, 80, 5974-5983. [CrossRef]

98. Hosokawa, T.; Ishii, Y.; Nikoh, N.; Fujie, M.; Satoh, N.; Fukatsu, T. Obligate bacterial mutualists evolving from environmental bacteria in natural insect populations. Nat. Microbiol. 2016, 1, 15011. [CrossRef] [PubMed]

99. Nikoh, N.; Hosokawa, T.; Oshima, K.; Hattori, M.; Fukatsu, T. Reductive evolution of bacterial genome in insect gut environment. Genome Biol. Evol. 2011, 3, 702-714. [CrossRef]

100. Brown, A.M.V.; Huynh, L.Y.; Bolender, C.M.; Nelson, K.G.; McCutcheon, J.P. Population genomics of a symbiont in the early stages of a pest invasion. Mol. Ecol. 2014, 23, 1516-1530. [CrossRef]

101. Kenyon, L.J.; Meulia, T.; Sabree, Z.L. Habitat visualization and genomic analysis of "Candidatus Pantoea carbekii," the primary symbiont of the brown marmorated stink bug. Genome Biol. Evol. 2015, 7, 620-635. [CrossRef]

102. Prado, S.S.; Almeida, R.P.P. Role of symbiotic gut bacteria in the development of Acrosternum hilareand and Murgantia histrionica. Entomol. Exp. Appl. 2009, 132, 21-29. [CrossRef]

103. Tada, A.; Kikuchi, Y.; Hosokawa, T.; Musolin, D.L.; Fujisaki, K.; Fukatsu, T. Obligate association with gut bacterial symbiont in Japanese populations of the southern green stinkbug Nezara viridula (Heteroptera: Pentatomidae). Appl. Entomol. Zool. 2011, 46, 483-488. [CrossRef]

104. Mondal, S.I.; Akter, A.; Koga, R.; Hosokawa, T.; Dayi, M.; Murase, K.; Tanaka, R.; Shigenobu, S.; Fukatsu, T.; Kikuchi, T. Reduced genome of the gut symbiotic bacterium "Candidatus Benitsuchiphilus tojoi" provides insight into its possible roles in ecology and adaptation of the host insect. Front. Microbiol. 2020, 11, 840. [CrossRef]

105. Kaltenpoth, M. Actinobacteria as mutualists: General healthcare for insects? Trends Microbiol. 2009, 17, 529-535. [CrossRef] [PubMed]

106. Sudakaran, S.; Retz, F.; Kikuchi, Y.; Kost, C.; Kaltenpoth, M. Evolutionary transition in symbiotic syndromes enabled diversification of phytophagous insects on an imbalanced diet. ISME J. 2015, 9, 2587-2604. [CrossRef]

107. Ohbayashi, T.; Futahashi, R.; Terashima, M.; Barriere, Q.; Lamouche, F.; Takeshita, K.; Meng, X.Y.; Mitani, Y.; Sone, T.; Shigenobu, S.; et al. Comparative cytology, physiology and transcriptomics of Burkholderia insecticola in symbiosis with the bean bug Riptortus pedestris and in culture. ISME J. 2019, 13, 1469-1483. [CrossRef]

108. Itoh, H.; Hori, T.; Sato, Y.; Nagayama, A.; Tago, K.; Hayatsu, M.; Kikuchi, Y. Infection dynamics of insecticide-degrading symbionts from soil to insects in response to insecticide spraying. ISME J. 2018, 12, 909-920. [CrossRef]

109. Tago, K.; Kikuchi, Y.; Nakaoka, S.; Katsuyama, C.; Hayatsu, M. Insecticide applications to soil contribute to the development of Burkholderia mediating insecticide resistance in stinkbugs. Mol. Ecol. 2015, 24, 3766-3778. [CrossRef]

110. Lee, J.; Kim, C.H.; Jang, H.A.; Kim, J.K.; Kotaki, T.; Shinoda, T.; Shinada, T.; Yoo, J.W.; Lee, B.L. Burkholderia gut symbiont modulates titer of specific juvenile hormone in the bean bug Riptortus pedestris. Dev. Comp. Immunol. 2019, 99, 103399. [CrossRef] [PubMed]

111. Kim, J.K.; Lee, J.B.; Huh, Y.R.; Jang, H.A.; Kim, C.H.; Yoo, J.W.; Lee, B.L. Burkholderia gut symbionts enhance the innate immunity of host Riptortus pedestris. Dev. Comp. Immunol. 2015, 53, 265-269. [CrossRef]

112. Kim, J.K.; Lee, J.B.; Jang, H.A.; Han, Y.S.; Fukatsu, T.; Lee, B.L. Understanding regulation of the host-mediated gut symbiont population and the symbiont-mediated host immunity in the Riptortus-Burkholderia symbiosis system. Dev. Comp. Immunol. 2016, 64, 75-81. [CrossRef] 
113. Kim, J.K.; Han, S.H.; Kim, C.H.; Jo, Y.H.; Futahashi, R.; Kikuchi, Y.; Fukatsu, T.; Lee, B.L. Molting-associated suppression of symbiont population and up-regulation of antimicrobial activity in the midgut symbiotic organ of the Riptortus-Burkholderia symbiosis. Dev. Comp. Immunol. 2014, 43, 10-14. [CrossRef] [PubMed]

114. Lee, J.B.; Park, K.E.; Lee, S.A.; Jang, S.H.; Eo, H.J.; Jang, H.A.; Kim, C.H.; Ohbayashi, T.; Matsuura, Y.; Kikuchi, Y.; et al. Gut symbiotic bacteria stimulate insect growth and egg production by modulating hexamerin and vitellogenin gene expression. Dev. Comp. Immunol. 2017, 69, 12-22. [CrossRef]

115. Hosokawa, T.; Kikuchi, Y.; Shimada, M.; Fukatsu, T. Symbiont acquisition alters behaviour of stinkbug nymphs. Biol. Lett. 2008, 4, 45-48. [CrossRef]

116. Itoh, H.; Tago, K.; Hayatsu, M.; Kikuchi, Y. Detoxifying symbiosis: Microbe-mediated detoxification of phytotoxins and pesticides in insects. Nat. Prod. Rep. 2018, 35, 434-454. [CrossRef] [PubMed]

117. Hosokawa, T.; Kikuchi, Y.; Shimada, M.; Fukatsu, T. Obligate symbiont involved in pest status of host insect. Proc. R. Soc. B 2007, 274, 1979-1984. [CrossRef]

118. Douglas, A.E. Strategies for enhanced crop resistance to insect pests. Annu. Rev. Plant. Biol. 2018, 69, 637-660. [CrossRef]

119. Arora, A.K.; Douglas, A.E. Hype or opportunity? Using microbial symbionts in novel strategies for insect pest control. J. Insect Physiol. 2017, 103, 10-17. [CrossRef]

120. Gong, J.T.; Li, Y.; Li, T.P.; Liang, Y.; Hu, L.; Zhang, D.; Zhou, C.Y.; Yang, C.; Zhang, X.; Zha, S.S.; et al. Stable introduction of plant-virus-inhibiting Wolbachia into planthoppers for rice protection. Curr. Biol. 2020, 30, 4837-4845. [CrossRef] [PubMed]

121. Machado, R.A.R.; Thonen, L.; Arce, C.C.M.; Theepan, V.; Prada, F.; Wuthrich, D.; Robert, C.A.M.; Vogiatzaki, E.; Shi, Y.M.; Schaeren, O.P.; et al. Engineering bacterial symbionts of nematodes improves biocontrol potential of the western corn rootworm. Nat. Biotechnol. 2020, 38, 600-608. [CrossRef] [PubMed]

122. Leonard, S.P.; Powell, J.E.; Perutka, J.; Geng, P.; Heckmann, L.C.; Horak, R.D.; Davies, B.W.; Ellington, A.D.; Barrick, J.E.; Moran, N.A. Engineered symbionts activate honey bee immunity and limit pathogens. Science 2020, 367, 573-576. [CrossRef] [PubMed]

123. Takeshita, K.; Kikuchi, Y. Riptortus pedestris and Burkholderia symbiont: An ideal model system for insect-microbe symbiotic associations. Res. Microbiol. 2017, 168, 175-187. [CrossRef] [PubMed]

124. Kaltenpoth, M.; Florez, L.V. Versatile and dynamic symbioses between insects and Burkholderia bacteria. Annu. Rev. Entomol. 2020, 65, 145-170. [CrossRef]

125. Douglas, A.E. The Drosophila model for microbiome research. Lab. Anim. 2018, 47, 157-164. [CrossRef]

126. Kwong, W.K.; Moran, N.A. Gut microbial communities of social bees. Nat. Rev. Microbiol. 2016, 14, 374-384. [CrossRef] [PubMed]

127. Li, H.; Young, S.E.; Poulsen, M.; Currie, C.R. Symbiont-mediated digestion of plant biomass in fungus-farming insects. Annu. Rev. Entomol. 2021. [CrossRef]

128. Gonella, E.; Orru, B.; Marasco, R.; Daffonchio, D.; Alma, A. Disruption of host-symbiont associations for the symbiotic control and management of pentatomid agricultural pests-a review. Front. Microbiol. 2020, 11, 547031. [CrossRef]

129. Kikuchi, Y.; Fukatsu, T. Live imaging of symbiosis: Spatiotemporal infection dynamics of a GFP-labelled Burkholderia symbiont in the bean bug Riptortus pedestris. Mol. Ecol. 2014, 23, 1445-1456. [CrossRef]

130. Kim, J.K.; Jang, H.A.; Won, Y.J.; Kikuchi, Y.; Heum Han, S.; Kim, C.H.; Nikoh, N.; Fukatsu, T.; Lee, B.L. Purine biosynthesisdeficient Burkholderia mutants are incapable of symbiotic accommodation in the stinkbug. ISME J. 2014, 8, 552-563. [CrossRef] 